\title{
Augmented Reality Based Media for Learning Biology During the Covid -19 Pandemic: Student Admission
}

\author{
Umar Abdul Labib ${ }^{1, *}$ Agung Wijaya Subiantoro ${ }^{2,}$ Wilis Putri Hapsari ${ }^{3}$ \\ ${ }^{1}$ Master of Biology Education, Faculty of Mathematics and Natural Sciences, Universitas Negeri Yogyakarta, \\ Indonesia \\ ${ }^{2}$ Department of Biology Education, Faculty of Mathematics and Natural Sciences, Universitas Negeri \\ Yogyakarta, Indonesia \\ ${ }^{3}$ Department of Research and Evaluation Education, Universitas Negeri Yogyakarta, Indonesia \\ *Corresponding author. Email: umar.labib1@gmail.com
}

\begin{abstract}
The advancement of digital technology in Industry 4.0 requires the ability to take advantage of technology as a whole and completely. Smart device technology which has many advanced features has been widely used in Indonesia, namely smartphones and is dominated by students. This technology tends not to be fully utilized in learning activities, including the use of augmented reality technology that does not support student learning. This condition needs to be addressed immediately, but it is necessary to conduct a test first on how to recognize students with augmented reality technology. This research was conducted by developing a questionnaire that shows the acceptability of augmented reality technology and its potential in biology learning activities. The conditions of the Covid-19 pandemic will make students even more intense in using this smartphone device. The use of digital technology devices has entered an educational aspect that has great potential in supporting learning activities, the use of Augmented Reality technology to support student observation objects in the field of biology education.
\end{abstract}

Keywords: Augmented reality, Student acceptance, Technology

\section{INTRODUCTION}

The industrial era 4.0 shows a significant increase in the use of technology, especially digital technology. The development of digital technology advances touches every aspect of human life. The most important aspect of human resource development and the formation of human character cannot be separated from advances in digital technology. Its increasingly massive use shows that in the current era, the need for digital technology is so high. High usage has changed the behavior of users who, in fact, do not fully utilize technology in aspects of life, to become more active in using digital technology in all aspects of life. Changing conditions require innovation that can adapt to different needs and lifestyles compared to the preindustrial era 4.0. Conditions like this are an important concern of education activists in particular, where teachers, lecturers, education supervisors, researchers, and others need innovation that is able to answer the challenges of technological progress in the current era. The industrial era 4.0 has begun to leave the habit of using conventional learning media because it is no longer effective in its application in learning practices. This is because it refers to current technological advances, then refers to student needs, motivation in learning, and improving student learning quality and quality to become more effective and efficient students. Improvement requires innovation by the quality to be achieved so that learning using digital technology is effective and efficient [1]. Innovation is a step needed to be able to survive and answer the challenges of the industry 4.0 era that utilizes digital technology.

The advancement of digital technology is the forerunner of every change that humans feel for every aspect of their life. Conditions like this cannot be avoided where digital technology users experience growth every year. The stickiness of using digital 
technology is proof that digital technology's human need is very high, for example, for smartphone users, especially in Indonesia. The data shows that 180 million Indonesians out of the total population of Indonesia are active users of smartphones so that in the annual period smartphone users in Indonesia have increased by $84 \%$, this percentage shows a very significant growth rate, in data compiled by UNICEF and the Ministry of Communication and Information or the Ministry of Communication and Information. The Republic of Indonesia and Berkman Harvard University Internet and Research Society Center. The results showed that the most widely used smartphone devices were children during school and adolescence, which were used as a means of supporting school work, social media, and entertainment or entertainment [2] [3]. This user data shows the potential use of digital technology that can be utilized in various aspects. Education, which is the closest aspect to children and adolescents as well as productive age, requires innovation in utilizing digital technology. This user data shows the potential use of digital technology that can be utilized in various aspects. Education, which is the closest aspect to children and adolescents as well as productive age, requires innovation in utilizing digital technology. This user data shows the potential use of digital technology that can be utilized in various aspects. Education, which is the closest aspect to children and adolescents as well as productive age, requires innovation in utilizing digital technology. In Indonesia, there have been many different types of media that can be used in learning, but their application in learning activities is still not optimal. In teaching-learning, teachers still tend to use conventional media and do not actively participate in applying current media in their teaching activities. The latest technology that can be applied in learning activities, especially biology, includes augmented reality technology that can be used in smartphone devices that are already owned by most students.

Augmented reality, commonly referred to as AR technology, is a renewable technology that uses digital objects virtually to appear in the real world [4]. Augmented Reality or AR is mobile, so it can be used wherever the user wants to use it so that in learning activities, it can make it easier for students to interact with virtual objects effectively [5]. Augmented Reality technology can display three-dimensional objects and present them in the real world so that students can receive a complete visualization represented by these three-dimensional objects and assist in abstract biology education or objects with limited observations if done conventionally. The use of three-dimensional digital objects makes abstract concepts in learning appear in the real world [6]. In this study, it will show how the reality of the use of cutting-edge technology has now been applied in learning activities, thus showing the extent to which progress in the use of technology in student learning activities or experiencing setbacks and not keeping up with current progress so that it will reduce the quality of student learning motivation that has been outlined in the first paragraph of this session, then whether this augmented reality technology can be accepted by students and prove whether it can potentially be a learning medium that will be liked by students and will be a potential learning technology in student learning activities [7]. The Technology Acceptance Model defines that PU (Perceived Usefulness) and PEU (Perceived Ease of Use) are the first two provisions of ATU (Attitude Towwar Using) users regarding the use of information technology [8] [9].

\section{RESEARCH METHODS}

The respondents of this study were high school students from several regions in Indonesia. Respondents consisted of educational unit levels from class ten X to twelve XII majoring in or concentrating on Natural Science Education and receiving Biology subjects. This study collected 207 respondents from various schools. The data collection process was carried out by students filling out a questionnaire regarding Augmented Reality learning media in online Biology subjects at the Covid 19 Pandemic. This study uses instruments that have been validated by experts. This research was developed using a technology acceptance model (TAM) based on the chart below [10];

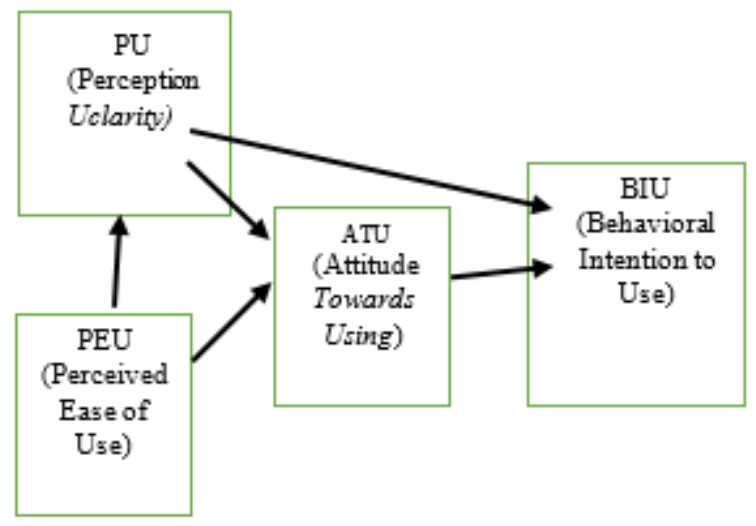

Figure 1 TAM chart adapted from Davis [7]

The number of items in this survey was 19 items using a 5 likert scale. There are 4 aspects that were assessed in this survey, including aspects of usability 
in items 1-9 as many as 9 items, aspects of ease of use felt in items number 10-14 as many as 5 items, aspects of attitude towards use. In items $15-17$ as many as 3 items and 2 aspects of use in items 18-19 are shown in table 3 [11] [12]. The data collected were analyzed

Table 1. Participant demographic profile using descriptive statistical analysis. Respondent data acquisition can be seen in table 1 below.

\begin{tabular}{|c|c|c|c|}
\hline Profile & Category & Total & Percentage $(\%)$ \\
\hline \multirow[t]{2}{*}{ Gander } & Boy & 72 & 35 \\
\hline & Girl & 134 & 65 \\
\hline \multirow[t]{3}{*}{ Class } & XIPA & 89 & 43 \\
\hline & XI IPA & 46 & 22.2 \\
\hline & XII IPA & 72 & 34.8 \\
\hline \multirow[t]{3}{*}{ Get to know the Media of Augmented Reality (AR) } & Ever & 56 & 27.1 \\
\hline & Never & 121 & 58.5 \\
\hline & Maybe & 30 & 14.5 \\
\hline \multirow[t]{3}{*}{ Using smartphone-based learning media } & Ever & 172 & 83.1 \\
\hline & Never & 19 & 9,2 \\
\hline & Maybe & 16 & 7,7 \\
\hline \multirow[t]{3}{*}{ Knowing Augmented Reality (AR) Learning Media } & Ever & 56 & 27.1 \\
\hline & Never & 121 & 58.5 \\
\hline & Maybe & 30 & 14.5 \\
\hline \multirow{3}{*}{$\begin{array}{l}\text { Learning media previously used based on Augmented Reality } \\
\text { (AR) }\end{array}$} & Ever & 19 & 9,2 \\
\hline & Never & 170 & 82.1 \\
\hline & Maybe & 18 & 8.7 \\
\hline \multirow[t]{2}{*}{ Watch videos using Augmented Reality Learning Media } & Ever & 168 & 81.2 \\
\hline & Never & 39 & 18.8 \\
\hline \multirow[t]{2}{*}{$\begin{array}{l}\text { Learning media that have been downloaded have been } \\
\text { downloaded }\end{array}$} & Can use it & 65 & 31.4 \\
\hline & Can't use it yet & 142 & 68.6 \\
\hline
\end{tabular}

The data was retested in the validity test of the questions using statistics to verify the validity of the data with the question items, shown in Table 2 as follows:

Table 2. The validity of the question item

\section{Question item number}

\begin{tabular}{|l|l|l|l|l|l|l|l|l|l|}
\hline & 1 & 2 & 3 & 4 & 5 & 6 & 7 & 8 & 9 \\
\hline PU & 0.778 & 0.802 & 0.808 & 0819 & 0.784 & 0846 & 0.775 & 0.704 & 0.792 \\
\hline PEU & 0.807 & 0.799 & 0.778 & 0844 & 0.769 & - & - & - & - \\
\hline ATU & 0864 & 0.829 & 0.799 & - & - & - & - & - & - \\
\hline BIU & 0.903 & 0.911 & - & - & - & - & - & - & - \\
\hline
\end{tabular}


Based on the data above, it shows that per question item can be obtained the product moment correlation value $r$ count people above 0.5 or $r$ count $>50 \%$ then the question item is declared valid [11], [12].

\section{RESULTS AND DISCUSSION}

In this article, the results of instrument testing will be presented in order to strengthen the results of validation by experts to make them more reliable and valid. For each question item 19 items have a Cronbach's Alpha reliability value of 0.958 which is perfectly represented [13] and able to reveal information [14]. In this study, various types of data have been obtained, along with the descriptions.

\subsection{Respondent Data Results}

The results of respondent data in this study were $(\mathrm{N}=207)$ including male students $(35 \%)$ and female students $(65 \%)$ were collected from the education level in class X IPA (43\%) Class XI IPA $(22.2 \%)$ and Class XII IPA $(34.8 \%)$ as a whole stated that they did not know and used Augmented Reality media in their learning activities (58.5\%). The data obtained shows that students have involved smartphone technology in biology learning activities by (83.1\%), in deepening knowledge about the use of augmented reality media by high school students in biology learning activities by $(58.5 \%)$ because they provide explanatory videos about the use augmented reality media in learning biology so that it can be watched by students (Figure 2), Then, so that students can feel and use augmented reality media in biology, a link is provided to install an augmented reality application demo (Figure 3 ). The next process is to fill out a questionnaire in the form of a digital questionnaire, the results of which can be seen in table 3.

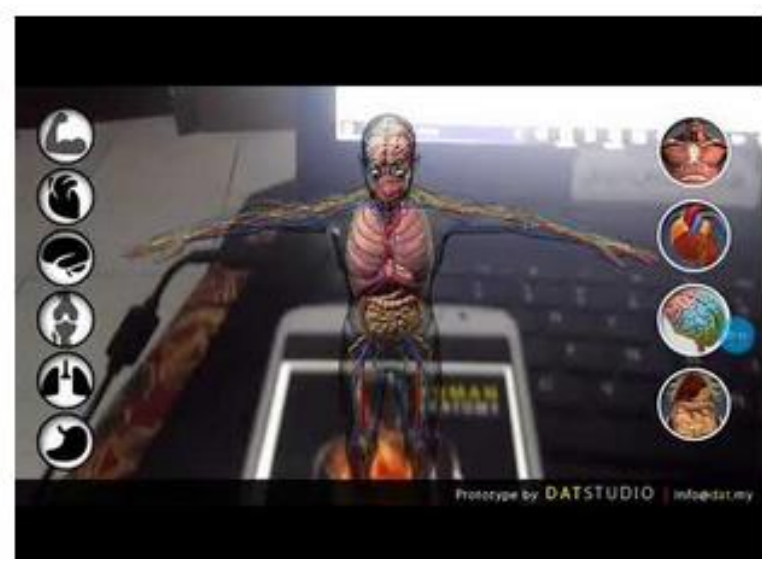

Figure 2. Video Explanation Regarding the Use of Augmented Reality Media in Biology

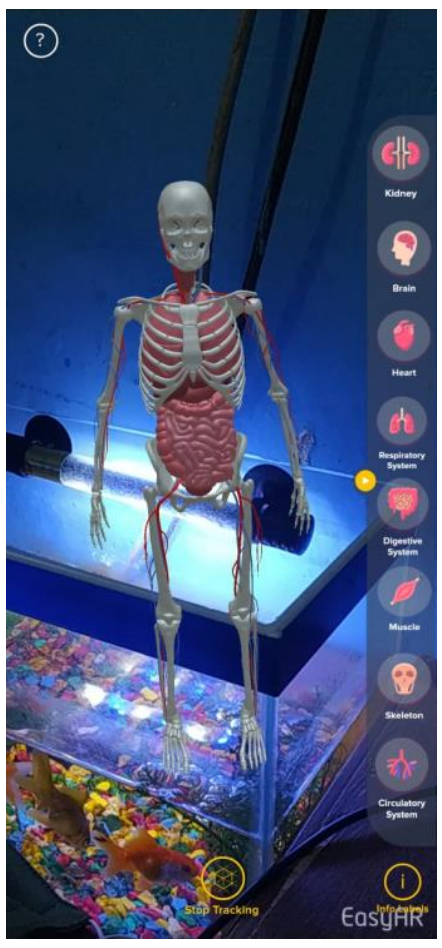

Figure 3. Showing examples of applications provided by researchers

The data displayed in table 3 provides an explanation of the frequency of respondents' answers on the Likert scale, the choices are STS (Strongly Disagree), TS (Disagree), N (Neutral), S (Agree), SS (Strongly Agree in the score represented by 1, 2,3,4 and 5. Based on the average value data that shows the agreed answer, in the table above it can be seen that the standard deviation value is lower than the average value, so the data tends to be closer to the average value [15]. From the data, the standard deviation value is smaller than the average value, so the data can be used as a representation of the entire data [16], it can be concluded that in this study on average it can be the conclusion of the study.

\subsection{Perceived Usefulness (PU)}

The questions in items 1 to 9 are indicator questions. The use of students in using augmented reality media is based on the extent of acceptance, agreement and trust in using AR media [7]. Based on the results of the data obtained, students agree to use augmented reality learning media to assist in learning activities, increase the meaning of enthusiasm for learning, assist students in better understanding concepts, help improve learning skills, increase interest in student learning activities, so that facilitate student learning activities, able to increase student motivation. 
Table 3. Descriptive statistics of the questionnaire results

\begin{tabular}{|c|c|c|c|c|c|c|c|c|c|}
\hline No & The essence of the question & $\begin{array}{l}\text { SD } \\
A^{(\%)}\end{array}$ & $\begin{array}{l}\text { DA } \\
(\%)\end{array}$ & $\begin{array}{l}\mathrm{N} \\
(\%)\end{array}$ & $\begin{array}{r}A \\
(\%)\end{array}$ & $\begin{array}{l}\text { SA } \\
(\%)\end{array}$ & $x \square$ & $\sigma$ & 9 \\
\hline 1 & Helps study material faster & $4^{3 .}$ & 2.9 & 25.0 & 45.6 & 3.4 & 3.82 & 0.937 & 0.792 \\
\hline 2 & $\begin{array}{l}\text { Increase enthusiasm and } \\
\text { motivation to learn }\end{array}$ & $4^{3 .}$ & 4.4 & 32.8 & 43.1 & 16.2 & 3.64 & 0.923 & - \\
\hline 3 & $\begin{array}{l}\text { Helps in understanding } \\
\text { concepts better }\end{array}$ & $5^{2 .}$ & 3.4 & 27.0 & 46.1 & 21.1 & 3.80 & 0.895 & - \\
\hline 4 & Improve study skills & 5 & 5.9 & 22.1 & 46.6 & 23.0 & 3.82 & 0.937 & - \\
\hline 5 & $\begin{array}{l}\text { Increase student interest in } \\
\text { learning }\end{array}$ & $9^{3 .}$ & 4.9 & 32.8 & 39.7 & 18.6 & 3.64 & 0.970 & \\
\hline 6 & $\begin{array}{l}\text { Assist in facilitating learning } \\
\text { activities }\end{array}$ & $9^{3 .}$ & 4.9 & 18.6 & 50.0 & 22.5 & 3.82 & 0.967 & \\
\hline 7 & $\begin{array}{l}\text { Can be a medium with high } \\
\text { potential for use in learning }\end{array}$ & $9^{3 .}$ & 4.4 & 19.1 & 43.6 & 28.9 & 3.89 & 1,002 & \\
\hline 8 & $\begin{array}{l}\text { Provide comfort while } \\
\text { studying }\end{array}$ & $\begin{array}{l}6 . \\
4\end{array}$ & 7.8 & 34.3 & 38.2 & 13.2 & 3.44 & 1,027 & \\
\hline 9 & Useful in learning & $4^{3 .}$ & 3.4 & 20.6 & 54.9 & 17.6 & 3.80 & 0890 & \\
\hline 10 & $\begin{array}{l}\text { Can be used and } \\
\text { understood easily }\end{array}$ & 2. & 4.9 & 28.9 & 51.5 & 12.3 & $\begin{array}{l}33.6 \\
8\end{array}$ & 6,743 & \\
\hline 11 & $\begin{array}{l}\text { Easy to apply in learning } \\
\text { activities }\end{array}$ & $5^{2 .}$ & 2.9 & 29.4 & 51.0 & 14.2 & 3.66 & 0847 & \\
\hline 12 & $\begin{array}{l}\text { Help improve skills in using } \\
\text { digital devices }\end{array}$ & 2. & 3.4 & 28.4 & 46.6 & 19.6 & 3.72 & 0.835 & \\
\hline 13 & Overall easy to use & 2. & 2.9 & 31.9 & 48.0 & 14.2 & 3.78 & 0867 & \\
\hline 14 & $\begin{array}{l}\text { Augmented Reality media } \\
\text { favored by students }\end{array}$ & $4^{3 .}$ & 5.9 & 42.2 & 37.7 & 10.8 & 3.68 & 0861 & \\
\hline 15 & $\begin{array}{l}\text { Fun when used in learning } \\
\text { activities }\end{array}$ & $9^{3 .}$ & 6.9 & 24.5 & 47.5 & 17.2 & 3.47 & 0890 & \\
\hline 16 & This medium is not boring & $4^{3 .}$ & 4.4 & 28.4 & 45.1 & 18.6 & $\begin{array}{l}18.3 \\
0\end{array}$ & 3,436 & \\
\hline 17 & $\begin{array}{l}\text { Don't mind using it in } \\
\text { learning }\end{array}$ & $\begin{array}{l}4 . \\
4\end{array}$ & 5.9 & 31.4 & 41.2 & 17.2 & 3.67 & 0.970 & \\
\hline 18 & $\begin{array}{l}\text { Able to improve skills in } \\
\text { using the latest media }\end{array}$ & $\begin{array}{l}4 . \\
4 \\
\end{array}$ & 4.9 & 33.3 & 40.2 & 17.2 & 3.71 & 0.936 & \\
\hline 19 & $\begin{array}{l}\text { Stimulate students' curiosity } \\
\text { in learning }\end{array}$ & $9^{5 .}$ & 3.9 & 30.4 & 41.7 & 18.1 & 3.61 & 0.984 & \\
\hline
\end{tabular}




\subsection{Ease of Use (PEU)}

Items 10 through 14 are statements from the PEU context. In student acceptance related to the use of augmented reality is a determinant in the aspect of use where students agree and accept that augmented reality can help in better learning activities because of the value of ease of use [7]. Based on the results of student responses, the questionnaire shows that they can use media to support learning activities to make learning easier, providing increased skills in using digital media.

\subsection{Attitude Towards Use (ATU)}

This study pays attention to the attitude aspect, where the attitude towards the application of augmented reality learning media is an evaluation of user interest in using augmented reality media. The results that have been collected show that high school students agree that students enjoy using augmented reality media and increase student enthusiasm and motivation to learn.

\subsection{Behavioral Intention to Use (BIU)}

The behavior of wanting augmented reality media shows a tendency to want to keep using augmented reality media both now and in the future with a value that is not boring and the desire to always try to optimize its use [17]. Based on these data, it can be seen that high school students agree that learning media is effective in providing better quality learning.

\subsection{Acceptance of Augmented Reality Learning Media according to TAM}

Based on the data that has been collected it can be concluded,

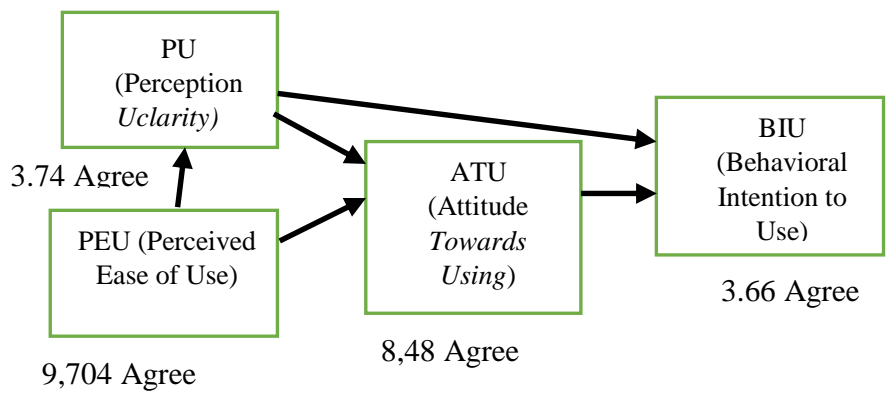

Figure 4. Summary of data results according to the TAM revenue stream adopted from Davis [7]

The average presentation of each point for TAM will get the highest percentage of each point from the five proposed scales as in Figure 4. In this figure it can be concluded that TAM in augmented reality learning media is the dominant suitability. So that student acceptance of augmented reality media is very good and has good potential in its application in learning.

\section{CONCLUSION}

Many high school students in Indonesia have the same perception of augmented reality learning media with Biology learning media and will support learning during the Covid-19 pandemic. High school students show that the average student agrees that each indicator of the application of augmented reality learning media that has been prepared in accordance with the TAM (Technology Acceptance Model) is seen in every aspect of student acceptance technology. In this explanation, it can be concluded that high school students can get augmented reality learning media in biology learning activities and can support learning during the Covid-19 pandemic. Based on the results of this study, it is necessary to develop learning media based on augmented reality and it is important to support learning biology. With this innovation and development, The quality of learning becomes more effective and meaningful and supports technological trends in the industrial era 4.0 so that learning becomes more sophisticated. This development is able to provide more meaningful learning and support the modern era.

\section{REFERENCES}

[1] H. Ellington, F. Percival, P. Race, Handbook of Educational Technology, Nichols Pub Co; Subsequent edition, 1993.

[2] G. Gayatri et al., Digital Citizenship Safety Among Children and Adolescents in Indonesia, Jurnal Penelitian dan Pengembangan Komunikasi dan Informmasi 6(1) (2015) 122672.

[3] Hendriyani, E. Hollander, L. d'Haenens, J.W. J. Beentjes, Children's Media Use in Indonesia, Asian Journal of Communication 22(3) (2012) 304-319.

DOI: http:///doi.org/10.1080/01292986.2012.662514

[4] E. Quintero, P. Salinas, E. González-Mendívil, H. Ramírez, Augmented Reality app for Calculus: A Proposal for the Development of Spatial Visualization, in: Procedia Computer Science, vol. 75, Elsevier, Amsterdam, 2015, pp. 301-305. DOI:

http:///doi.org/10.1016/j.procs.2015.12.251 
[5] T. Teo, L. Lawrence, G. A. Lee, M. Billinghurst, M. Adcock, Mixed reality remote collaboration combining 360 video and 3D reconstruction, in: Proceedings of Conference on Human Factors in Computing Systems, Association for Computing Machinery, 2019, pp. 1-14. DOI: http:///doi.org/10.1145/3290605.3300431

[6] S. Geometri, Ö. Kullanılan, Ö. Etkisi, Effect of Teaching Geometry with Use Cabri 3D in Eighth Grade on Conceptual Learning, Turkish Journal of Computer and Mathematics Education 4(3) (2013) 224-241,

[7] F. D. Davis, Perceived Usefulness, Perceived Ease of Use, and User Acceptance of Information Technology, MIS Quarterly Management Information Systems 13(3) (1989) 319-339. DOI: http:///doi.org/10.2307/249008

[8] C. Bertagnolli, V. Venkatesh, Q.L. Chen, Z. H. Zhou, Determinants of Perceived Ease of Use : Integrating Control, Intrinsic Motivation, Acceptance Model, Inorganic Chemistry Communications 11(3) (2000) 319-340.

[9] M.K.O. Lee, C.M.K. Cheung, Z. Chen, Acceptance of Internet-Based Learning Medium: The Role of Extrinsic and Intrinsic Motivation, Information and Management 42(8) (2005) 1095-1104.

DOI: http:///doi.org/10.1016/j.im.2003.10.007

[10] J.C.M. Rodrigues Pinho, A.M. Soares, Examining The Technology Acceptance Model in The Adoption of Social Networks, Journal of Research in Interactive Marketing 5 (2011) 116129.

DOI: http:///doi.org/10.1108/17505931111187767

[11] A. Field, Discovering Statistics Using IBM SPSS Statistics. London: SAGE Publications Ltd, 2013.

[12] Leech, IBM SPSS for Intermediate Statistics, 2012.

[13] K.A. Pituch, J.P. Stevens, Applied multivariate statistics for the social sciences: Analyses with SAS and IBM's SPSS, 2016.

[14] J.F. Hair, Multivariate Data Analysis with Readings, Pearson Prentice Hall, 2006.

[15] J. Bland, D. Altman, Statistics notes: Measurement error, British Medical Journal 312, 1996.
[16] H. B. Al-khatib, Predicting Financial Distress of Public Companies Listed in Amman Stock Exchange, European Scientific Journal 8(15) (2012) 1-17.

[17] M. Faraj, Generation of runtime execution traces of applications and associated problem determination, US Patent Journal 6 (2004) 802. 